\title{
Forensic science in Pakistan; present and future
}

\author{
Rana Muhammad Mateen ${ }^{1 *}$, Asma Tariq ${ }^{2}$ and Nouman Rasool ${ }^{3}$
}

\section{Main text}

To the editor

Forensic science has been a key pillar in criminal justice system all over the world (Petherick et al., 2010). In Pakistan, forensic has been ignored for a long time. The ongoing terrorism gave a wake-up call to the establishment and untiring efforts were made for the establishing and proper functioning of the forensic laboratory to help criminal investigations (Petherick et al., 2009). Since 2001, authorities have been revamping forensic science infrastructure across the country to aid crime investigation. The National Forensic Science Agency (NFSA) was approved by the Executive Committee of the National Economic Council (ECNEC) as an autonomous body in 2002 having departments of crime scene Investigation, trace chemistry, questioned documents and digital forensics (National Forensic Science Agency, n.d.). Its objective was to help establish other forensic science laboratories across the country and to provide teaching and training facilities throughout Pakistan, which is still not achieved. In Punjab province, Punjab Forensic Science Agency (PFSA) Act was passed on October 2007 for the establishment of the Forensic Science Agency which ultimately lead to the establishment of the Punjab Forensic Science Agency on 2012 having fourteen departments under one roof. The departments include audio video analysis, computer forensic unit, crime and death scene, DNA and serology, forensic photography, narcotics, toxicology, trace evidence, polygraph, firearm and tool marks, latent fingerprints, pathology and questioned documents (Punjab Forensic Science Agency, n.d.). In Sindh province, Sindh Forensic Science Agency act was passed on August, 2017 but so far no laboratory has been established. DNA testing facility available in Jamshoro, Sindh which provides research as well as forensic DNA testing. Besides this, government of Sindh is making efforts for establishment of Forensic DNA testing laboratory in Karachi University.

\footnotetext{
* Correspondence: rana.mateen@umt.edu.pk

${ }^{1}$ Department of Life sciences, University of Management and Technology,

Lahore, Pakistan

Full list of author information is available at the end of the article
}

Khyber Pakhtunkhwa police has established Forensic Science Laboratory and Institute of Forensic Science in Peshawar on December, 2017 to provide preliminary forensic facilities and to bridge the gap between forensic awareness and criminal investigation practices. In Balochistan province of Punjab, an act was passed for the establishment of Balochistan Forensic Science Agency on August, 2015 but no forensic facility has yet been established. At present, NFSA and PFSA are providing many important investigation leads in various hideous crimes. The advent of DNA data base recently at PFSA has proved a major breakthrough in solving crimes through DNA profile comparison, not only exonerating the innocent, but also in catching the real culprit (Punjab Forensic Science Agency, n.d.). Now general public and judiciary of Pakistan are relying heavily on Forensic evidences in trial cases and making decisions. As forensic science popularity increases in the country so does the backlog. More and more cases are being received each day which is causing delay in the case processing and ultimately delayed justice. There is a need to increase the capacity and number of the Forensic laboratories across the country as current facility is insufficient keeping in mind the large number of cases coming from big population of Pakistan (Population Welfare Department, n.d.).

\section{Conclusion}

As population of Punjab province of Pakistan is 110 million, a single forensic laboratory at provincial level cannot fulfil the requirement of this province. There is a dire need to establish and strengthen the infrastructure of the forensic laboratories in Sindh, Khyber Pakhtunkha and Bolochistan province of Pakistan. It is also noteworthy to mention that that capacity building, continuous learning and proper trainings of the personnel working in these laboratories is necessary to counter the increasing amount of criminal cases in Pakistan for smooth functioning of judiciary system. 


\section{Abbreviations}

ECNEC: Executive Committee of the National Economic Council;

NFSA: National Forensic Science Agency; PFSA: Punjab Forensic Science

Agency

\section{Funding}

Not Applicable.

\section{Availability of data and materials}

Data sharing not applicable to this article as no datasets were generated or analysed during the current study.

\section{Author's contribution}

RMM (Data curator, writing). AT (Data curator, writing). NR (Data curator, review). All authors read and approved the final manuscript.

\section{Ethics approval and consent to participate}

Not applicable.

\section{Consent for publication}

Not applicable.

\section{Competing interests}

The authors declare that they have no competing interests.

\section{Publisher's Note}

Springer Nature remains neutral with regard to jurisdictional claims in published maps and institutional affiliations.

\section{Author details}

${ }^{1}$ Department of Life sciences, University of Management and Technology, Lahore, Pakistan. ${ }^{2}$ Institute of Biochemistry \& Biotechnology, University of the Punjab, Lahore, Pakistan. ${ }^{3}$ Department of Life sciences, University of

Management and Technology, Lahore, Pakistan.

Received: 6 June 2018 Accepted: 26 July 2018

Published online: 01 August 2018

\section{References}

National Forensic Science Agency n.d. http://www.nfsa.gov.pk. Accessed on 5 June 2018

Petherick W, Turvey BE, Ferguson CE (2009) Forensic criminology. Academic Press, Peace Kashmir Organization. Growing Terrorism in Pakistan. http:// www.peacekashmir.org/views-articles/2012/1216-growing-terrorism-inpakistan.html. Accessed on 6 June 2018

Population Welfare Department, Government of Punjab n.d. https://pwd.punjab. gov.pk/population_profile Accessed on 6 June 2018

Punjab Forensic Science Agency n.d. http://pfsa.gop.pk/?page_id=4792. Accessed on 5 June 2018

\section{Submit your manuscript to a SpringerOpen ${ }^{\mathcal{O}}$ journal and benefit from:}

- Convenient online submission

- Rigorous peer review

- Open access: articles freely available online

High visibility within the field

- Retaining the copyright to your article 